University of Nebraska - Lincoln

DigitalCommons@University of Nebraska - Lincoln

Papers in Molecular Chemistry

Chemical and Biomolecular Engineering

Research and Publications

$5-1-1993$

Reaction Kinetics Analysis of Urethane Polymerization to Gelation

B Liu

Caltex services Coporation, Dallas, Texas 75261-9500

Hossein Noureddini

Department of Chemical Engineering, University of Nebraska-Lincoln, hnouredd@unlnotes.unl.edu

J S. Dorsey

Department of Chemical Engineering, University of Nebraska-Lincoln

Delmar C. Timm

University of Nebraska-Lincoln, dtimm1@unl.edu

Follow this and additional works at: https://digitalcommons.unl.edu/chemengmolecular

Part of the Chemical Engineering Commons

Liu, B; Noureddini, Hossein; Dorsey, J S.; and Timm, Delmar C., "Reaction Kinetics Analysis of Urethane Polymerization to Gelation" (1993). Papers in Molecular Chemistry. 4.

https://digitalcommons.unl.edu/chemengmolecular/4

This Article is brought to you for free and open access by the Chemical and Biomolecular Engineering Research and Publications at DigitalCommons@University of Nebraska - Lincoln. It has been accepted for inclusion in Papers in Molecular Chemistry by an authorized administrator of DigitalCommons@University of Nebraska - Lincoln. 
B. Liu, H. Noureddini, J. S. Dorsey, and D. C. Timm, Reaction Kinetics Analysis of Urethane Polymerization to Gelation, Macromolecules Macromolecules; 1993; 26(23); 6155-6163.

\title{
Reaction Kinetics Analysis of Urethane Polymerization to Gelation
}

\author{
B. Liu ${ }^{+}$, H. Noureddini, ${ }^{*}$ J. S. Dorsey", and D. C. Timm* \\ + Caltex Services Corp.
}

* Department of Chemical Engineering, University of Nebraska-Lincoln, Lincoln, Nebraska 68588

Macromolecules; 1993; 26(23); 6155-6163.

Received January 25, 1993; Revised Manuscript Received May 24, 1993

Abstract published in Advance ACS Abstracts, October 15, 1993.

Copyright (C) 1993 American Chemical Society.

The American Chemical Society allows the posting of only the title, abstract, tables, and figures from articles appearing in the Macromolecules.

This article is published online at http://pubs.acs.org/cgi-

bin/archive.cgi/mamobx/1993/26/i23/pdf/ma00075a003.pdf

\section{ABSTRACT:}

A chemical reaction analysis of a thermosetting, urethane resin formulated from a triol and a diisocyanate is reported. Population density distributions of oligomeric molecules, monomer concentration, the cumulative molar concentration of intramolecular bonds, the resin's average molecular weights, and extent of reaction were determined as a function of time. Rate expressions for intermolecular reactions were first order with respect to the concentration of each reactant and were proportional to the functionality of their respective chemical moieties. Rate expressions for intramolecular reactions were first order with respect to the concentration of the reactant and were proportional to the functionality of the limiting chemical moiety on the reactant. The initial ratio of the chemical equivalents and effects of dilution were incorporated into numerical simulations. Stanford and Stepto's experimental data were analyzed. Gel points and the concentration of intramolecular bonds were correlated as a function of conversion. Intramolecular reaction rate expressions derived with the aid of Gaussian chain statistics require the molar concentrations of all chemical isomers of a specified chemical composition. The present reaction rate expression allows chemical isomers to be lumped into a single population density distribution variable, substantially reducing the dimensions of the simulation. Numerical results demonstrate that the simplified rate expression is an excellent. 
B. Liu, H. Noureddini, J. S. Dorsey, and D. C. Timm, Reaction Kinetics Analysis of Urethane Polymerization to Gelation, Macromolecules Macromolecules; 1993; 26(23); 6155-6163.

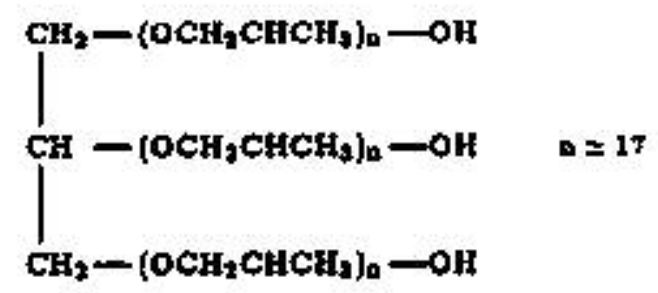

Fizure 1. Niax triol a propylene caxide adduct of glycerol.

Copyright (C) 1993 American Chemical Society.

MONOMER

B - 百

Pais

$\operatorname{TR}[\boldsymbol{c} \cdot \mathrm{t}$

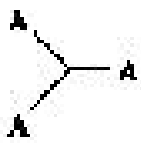

TRTMYH<smiles>CC(C)C=CC(C)C</smiles>

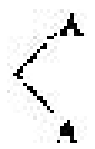<smiles>[124In]</smiles>

ELIGONEK

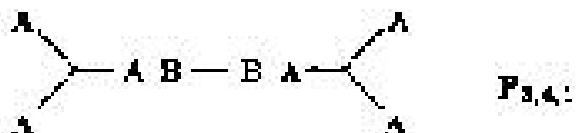<smiles>[P][P]</smiles><smiles>[AlH][AlH]</smiles>

$$
\text { A } \mathrm{A}-\mathrm{B}
$$

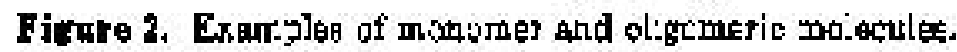

Copyright (C) 1993 American Chemical Society. 
B. Liu, H. Noureddini, J. S. Dorsey, and D. C. Timm, Reaction Kinetics Analysis of Urethane Polymerization to Gelation, Macromolecules Macromolecules; 1993; 26(23); 6155-6163.

Table L Camparion of Pepulation Dentity Dirtributious

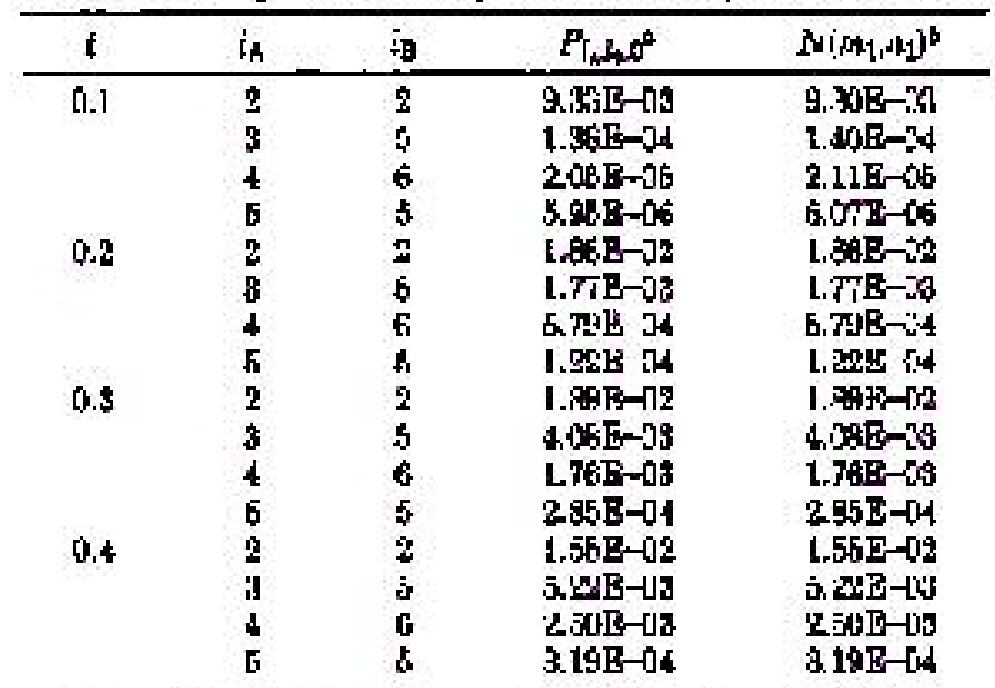

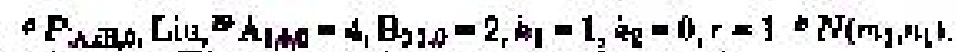

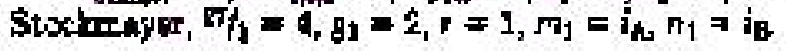

Copyright (C) 1993 American Chemical Society. 
B. Liu, H. Noureddini, J. S. Dorsey, and D. C. Timm, Reaction Kinetics Analysis of Urethane Polymerization to Gelation, Macromolecules Macromolecules; 1993; 26(23); 6155-6163.

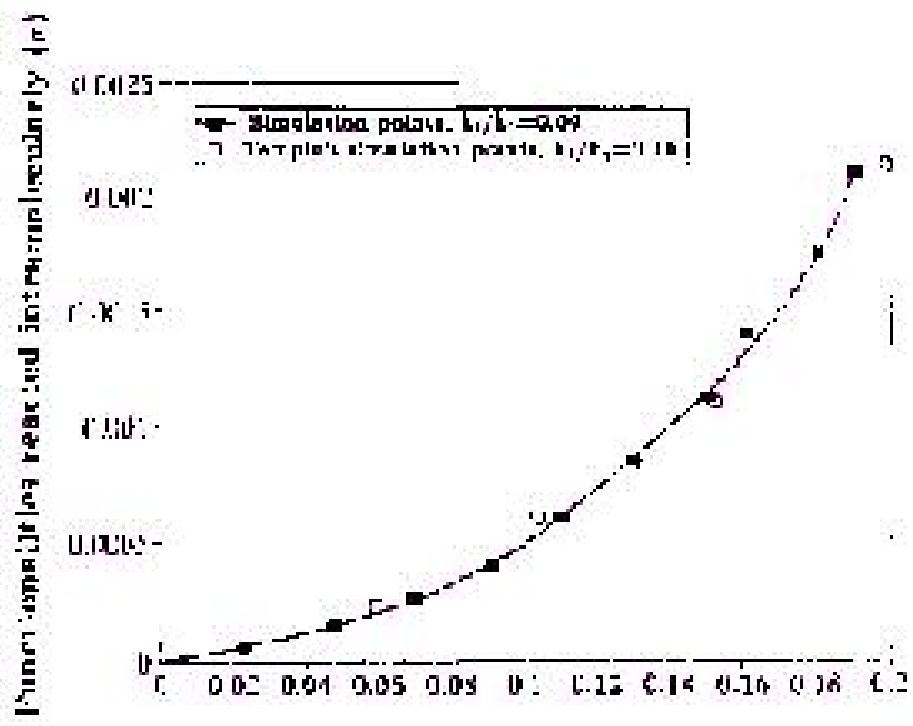

Functisnallites reacted intcrmolscalory la:

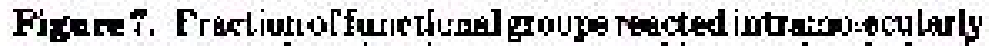

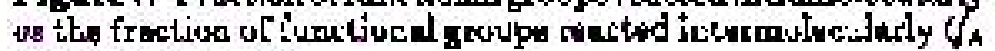
$=?, f_{0}=3 \cdot r=1$ ).

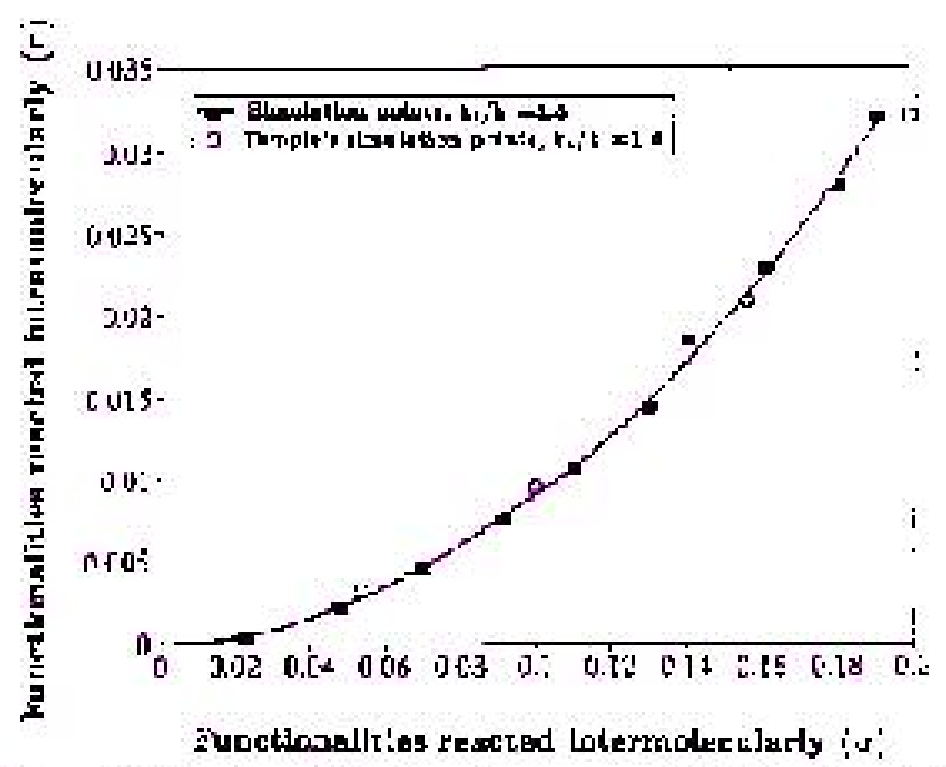

Fugare8. Fraction af functiona] porspe racted intramolecularly

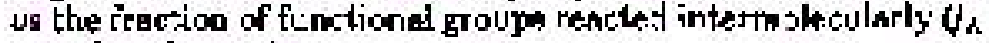
$-2,1,=6, z=1$.

Copyright (C) 1993 American Chemical Society. 
B. Liu, H. Noureddini, J. S. Dorsey, and D. C. Timm, Reaction Kinetics Analysis of Urethane Polymerization to Gelation, Macromolecules Macromolecules; 1993; 26(23); 6155-6163.

Copyright (C) 1993 American Chemical Society.

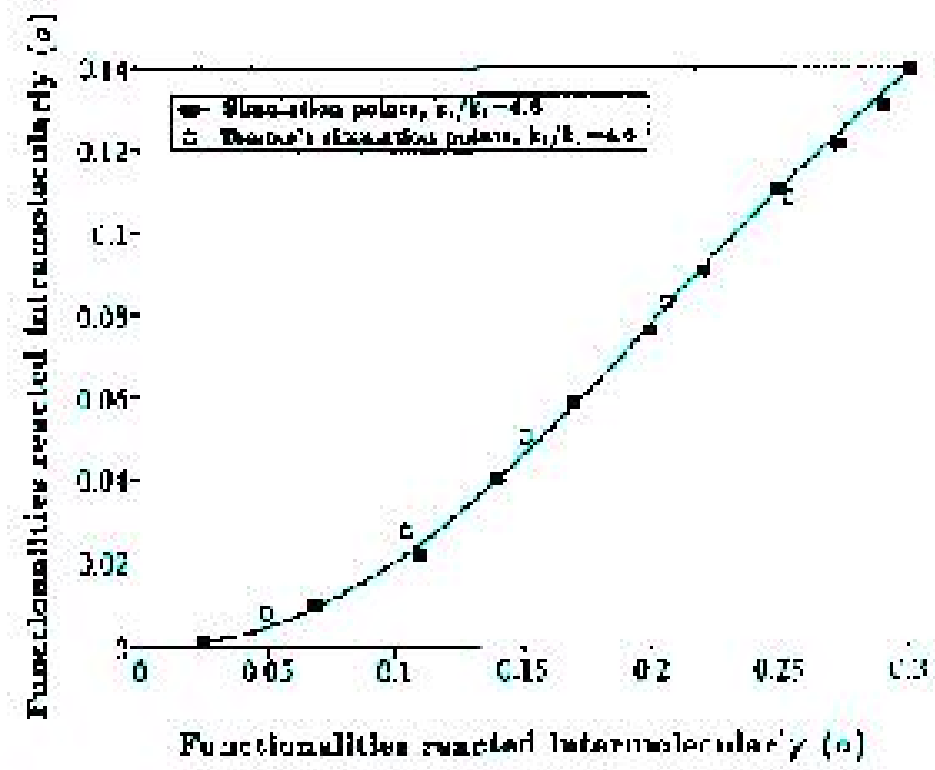

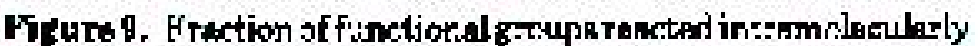

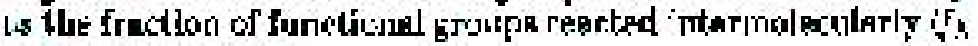
$=2, f_{B}-9, r-11$ 